Society for the Anthropology of Work • Essential Labor

\title{
Human Sacrifices, not Heroes: U.S. Essential Workers and the COVID-19 Pandemic
}

Shan-Estelle Brown, Zoe Pearson

Published on: Nov 02, 2020

DOI: $10.21428 / 1 \mathrm{~d} 6 \mathrm{be} 30 \mathrm{e} .53617 \mathrm{da} 1$

License: Creative Commons Attribution 4.0 International License (CC-BY 4.0). 
In May 2020, a priest in the Indian state of Odisha allegedly beheaded a man as a human sacrifice to end the COVID-19 pandemic. When he was interrogated by police, the priest claimed that the goddess he worships told him to do it in a dream. As sensational as this story may be, a less obvious form of human sacrifice has been normalized in the United States for quite some time: the sacrifice of essential workers' lives to prop up a faltering economy. In this essay, we argue that essential in this pandemic has become a synonym for expendable. Attempts to balance economic concerns with public safety in the absence of a coordinated, evidence-based public health response have shifted difficult choices to individuals who either face financial ruin or risk infection at work. In the media, we have seen reports of essential workers receiving gratitude and applause or, alternatively, coercive demands instead of personal protective equipment (PPE), hazard pay, health care coverage, and other forms of material compensation. As localities in the United States reopened and as more workers were placed at risk while doing work that ordinarily would not be life-threatening, we have been prompted to consider what labor is truly essential, who the labor is essential to, and who it is performed by, as well as whether it is justified to sacrifice human beings so as to save an economy that does not serve them. What we are seeing is not heroism. It is involuntary human sacrifice, made to look voluntary.

Human sacrifice has not been a major focus of research in archaeology and anthropology (Schwartz 2017). It has, however, been argued to fulfill social functions such as instilling fear, appeasing the gods, preventing bad things from happening, or precipitating desired events such as economic success. The anthropologist Dean Sheils (1980: 245) used evidence from 107 societies around the world to argue that "human sacrifice occurs only in those societies in which human life takes on exceptional economic value"; thereby, human sacrifices give up their potential output to satisfy deities. Human sacrifice has also been said to facilitate social stratification and a shift to strictly inherited class systems (Watts et al. 2016). On this account, the well-to-do sought to solidify a class structure and thus lower their own likelihood of being sacrificed. This is, arguably, the situation that we are in with COVID-19, where individuals doing their jobs are recast as either heroes or necessary casualties to maintain the American economy. Hours after being released from Walter Reed National Military Medical Center, where he received care after contracting the coronavirus, President Donald Trump tweeted that COVID-19 was something for Americans to learn to live with rather than "close down our country."

In the early days of the pandemic in the United States, people who were not essential workers were asked to sacrifice travel, time with family and friends, and other experiences to keep others safe. Essential workers were still tirelessly working at their jobs; some got sick and died. Throughout the summer of 2020, calls for sacrifices only increased with broader swaths of the population being forced to give up their lives in order to "Open Up America Again." The lieutenant governor of Texas, Dan Patrick, urged senior citizens to "take a chance on their survival" for the sake of "keeping the America that all America loves" for younger generations. According to Patrick, economic collapse would be a 
fate worse than death, and so Americans needed to get back to work. Of course, the America to which Patrick is referring had balked at dedicating resources to the elderly, disabled, nonwhite, and poor long before the COVID-19 pandemic began.

Health and economic issues are intertwined worldwide, but especially so in the United States, where access to health insurance depends on consistent employment. People of color have been especially impacted by the designation of essential work since they tend to receive less pay, are more likely to have underlying conditions that could lead to severe illness from COVID-19, and are more likely to live in a multigenerational household (Lofquist 2012; Family Caregiver Alliance 2016; McNicholas and Poydock 2020). In other words, Black, Indigenous, and people of color (BIPOC) are less likely to have the kind of profession that allows for working from home or taking leaves of absence, are less likely to have the financial safety net needed to stay out of work for a prolonged period of time, and are more likely to expose vulnerable people within their own homes to COVID-19 if they are designated as essential workers. While BIPOC adults are worrying about the coronavirus, white adults reported less concern about getting the virus and spreading it to others.

Not wanting to get sick is not enough justification for essential workers to receive the support and resources necessary to keep themselves and their loved ones healthy. To rationalize public acceptance of essential workers' heavy burden and to make everyone else feel better, media accounts branded essential workers as "heroes." Heroism is associated with being selfless, but it is based on the assumption that the hero is taking on personal risk voluntarily and out of a sense of morality. We argue that the absence of other forms of support makes these decisions to work coercive.

A widely publicized phenomenon during the spring shutdown was the sunset celebration of essential workers in major cities like New York. Yet the daily applause sessions for health care workers rang hollow. As the writer and grocery store worker Karleigh Frisbie Brogan noted, "I have a problem with all this hero talk. It's a pernicious label perpetuated by those who wish to gain something-money, goods, a clean conscience - from my jeopardization." Those who stand to gain include grocery store owners, people working nonessential jobs, people who may not realize just how much they benefit from the labor of essential workers, and politicians who can point to those attempting to work under pandemic conditions and insist that the situation is not that bad.

Although it is difficult to know the demographics of people who participated in the applause ritual, some of these clapping Americans may be the same ones who do not support expanding Medicaid for low-income people, who believe employers should not be paying for their employees' health care coverage, and who vote for politicians who defund health care and public health institutions. Some may refuse to wear masks to limit the spread of COVID-19 and yet still expect their own lives to be saved by health care workers who lack the resources to protect themselves. The disconnect between the performative gratitude they show for essential workers and the material support they are willing 
to offer and advocate for makes their applause the point at which their generosity and goodwill end. Meanwhile, as the applause has dwindled, movements like White Coats For Black Lives and \#GetUsPPE have helped health care workers to leverage their supposed hero status into needed equipment and workplace protections, as well as to support the Black Lives Matter movement. Health professionals are still doing their work, albeit with less media coverage and fewer public displays of support, even as COVID-19 is now the third leading cause of death in the United States.

Some essential workers have even been blamed for contracting the coronavirus. Florida Governor Ron DeSantis claimed that "overwhelmingly Hispanic" farmworkers and day laborers were driving the spike in COVID-19 cases within the state, despite evidence pointing to early state reopening as the driving factor behind the increase. The Chief Justice of the Wisconsin Supreme Court, Patience Roggensack, downplayed the spread of COVID-19 around the city of Green Bayby claiming that the increase in cases was not from "regular folks in Brown County," but rather from the area's meatpacking workers. These workers have faced claims that their multigenerational households, lack of PPE, and low testing rates are behind outbreaks in their communities, rather than the unsafe working conditions, limited access to health care, and low incomes that predispose them to COVID-19. Agricultural workers are not regarded as heroes, although it is their labor that has kept food on the table of American families, because they lack the autonomy to decide whether to return to work. They must return to meet their basic needs because there is no safety net for them if they do not. This constrained choice has forced essential workers to sacrifice themselves to keep the economy running.

As educational institutions were pushed toward reopening, either by college administrators fearing bankruptcy, governors hoping to get their workforces back to full productivity, or parents fearing that their children would fall behind in meeting learning milestones, the pool of expendables has grown still larger. Teachers, janitors, cafeteria workers, counselors, and other already underpaid and overworked staff members returned to work amid a patchwork of openings, closings, shelter-in-place orders, and outbreaks. In a few cases, parents sent their children to school knowing that they were infected with the coronavirus. If essential workers have limited autonomy, then their children have even less. Wealthier parents unsure about the safety of their children's schools have developed independent teaching "pods" that may have purposefully excluded children of essential workers. What if we placed our focus on controlling COVID-19 outbreaks instead of treating disease prevention as harmful to the economy? After all, we can work with lagging students and less productive parents; we can't work with dead ones.

Essential workers should not be the only people advocating for essential workers. Other segments of the population can no longer stand idly by as these workers are sacrificed because they have no choice but to put themselves in harm's way. This practice of modern human sacrifice cannot stand in a country that truly believes in freedom, and it is the responsibility of the American people to reaffirm their 
belief in this ideal by working toward the liberation of subjugated people with their votes, voices, and actions.

\section{Acknowledgments}

This essay grew out of a research project on mobile health and informal caregiving as part of the Rollins College Student-Faculty Collaborative Scholarship Program, which offers undergraduate students the opportunity to participate in high-level scholarly research.

\section{Author Bios}

Shan-Estelle Brown is Assistant Professor of Anthropology and co-coordinator of the Global Health Program at Rollins College in Winter Park, Florida. Her research interests include community-engaged research, improving patient-centered outcomes with medical technologies, perceptions of risk and well-being, and identifying structural facilitators and barriers to health care.

Zoe Pearson is a junior at Rollins College, who is pursuing a major in biochemistry and a minor in global health. Her research project with Professor Brown used human-centered design and one-on-one interviews with informal caregivers to create guidelines for mobile health apps, specifically to address caregivers' needs.

\section{Preview Image}

Courtesy of Gilbert Mercier.

\section{References}

Family Caregiver Alliance. 2016. “Caregiver Statistics: Demographics.” Fact sheet, updated April 17, 2019.

Lofquist, Daphne A. 2012. "Multigenerational Households: 2009-2011." American Community Survey Brief. Washington, DC: United States Census Bureau.

McNicholas, Celine, and Margaret Poydock. 2020. "Who Are Essential Workers? A Comprehensive Look at Their Wages, Demographics, and Unionization Rates." Working Economics Blog, May 19.

Schwartz, Glenn M. 2017. “The Archaeological Study of Sacrifice." Annual Review of Anthropology 46(1): 223-40.

Sheils, Dean. 1980. “A Comparative Study of Human Sacrifice.” Cross-Cultural Research 15(4): 245-62.

Watts, Joseph, Oliver Sheehan, Quentin D. Atkinson, Joseph Bulbulia, and Russell D. Gray. 2016. “Ritual Human Sacrifice Promoted and Sustained the Evolution of Stratified Societies." Nature 532(7598): 228- 
31. 